\title{
JÚLIA LOPES DE ALMEIDA: A BUSCA DA LIBERAÇÃO FEMININA PELAPALAVRA
}

Cátia Toledo Mendonça*

Túlia Lopes de Almeida é um nome que ainda não teve a atenção merecida para sua obra. Romancista e dramaturga que se projetou no início do século $\mathrm{XX}$, foi esquecida pela crítica falocêntrica, que a ela reservou um papel secundário.

Apontada pela crítica feminista como inovadora, acusada por Nelly Novaes Coelho de "confirma(r) a ideologia dominante e até mesmo reforça(r) a dualidade contraditória com que a tradição estigmatizou a mulher", ${ }_{1}^{1}$ Júlia Lopes de Almeida tem uma produção considerável, que passa pela literatura infantil, por matérias jornalísticas, romances e peças teatrais.

Neste ensaio faz-se uma leitura parcial de sua obra, uma vez que foram deixadas de lado várias de suas narrativas e peças, mas pretende-se apontar a existência de um fio condutor, que é a questão feminina, discutida principalmente sobre o aspecto do casamento e da instrução na vida da mulher.

Para tanto, foram analisadas duas de suas narrativas - $A$ Intrusa e $A$ Falência -, alguns artigos e uma de suas peças - A Herança -, que foi, inicialmente, o principal interesse deste trabalho.

* Doutoranda em Estudos Literários - UFPR. Trabalho sob orientação da prof. ${ }^{\text {a }}$ Dr. ${ }^{a}$ Marta Morais da Costa.

1 COELhO, N. N. Literatura: arte, conhecimento e vida. São Paulo: Petrópolis, 2000. p. 109. 
Fez-se necessário, também, situar sua obra num contexto nacional, para que fosse melhor percebida. Além disso, a crítica publicada na época da encenação auxilia para uma visão de sua obra, levando-se em conta a recepção em épocas diferentes.

Pretende-se, ao final, perceber com melhor nitidez o papel que esta dramaturga e romancista desempenhou em sua época, como intelectual preocupada com a mulher e sua situação na sociedade.

Pretende-se, também, esclarecer a situação duvidosa que cerca sua obra em relação a essas mesmas questões: se é conservadora ou se há uma proposta nova, de acordo com as teorias feministas de sua época.

Finalmente, pretende-se examinar sua peça $A$ Herança, como peça importante dentro do conjunto da obra desta escritora.

\section{$\mathrm{O}$ início do século XX: a literatura e o teatro brasileiro}

O período que antecedeu a Semana de Arte Moderna foi, para a literatura e também para o teatro, época de pouca produção. Embora hoje exista, com o benefício do distanciamento, uma seleção de nomes que se destacam no PréModernismo, reportando-se aos críticos da época, encontra-se um estado de desalento frente às manifestações artísticas nessa área.

No final do século XIX, em 1893, em artigo publicado em O Álbum, Aluísio Azevedo queixava-se da falta de leitores. No mesmo ano, Capistrano de Abreu lamenta a situação da literatura.

No teatro a situação não era muito diferente.

Em 1901, no texto intitulado Carta para a província, José Veríssimo denuncia o desamparo do teatro fluminense, apontando-o como "uma das coisas mais decadentes, mais em atraso, menos digna de uma grande cidade culta".

O crítico atribui várias razões para a crise, como, por exemplo, o fato de não existir o hábito de freqüentar o teatro, principalmente dentre os homens de letras, que, como ele, pouco iam assistir aos espetáculos. Por outro lado, quem freqüentava as casas teatrais, preferia os espetáculos que vinham de fora, "o teatro exótico, as sumidades, (...) as mediocridades, forasteiras em tournée pela América". ${ }^{3}$

2 VERRÍSSIMO, J. O que é Literatura? e outros escritos. São Paulo: Landy, 2001. p. 231 .

3 VERÍSSIMO, op. cit., p. 23. 
O conceituado crítico chama atenção também para a falta de boas casas de espetáculo, pois, em sua opinião, não há "nenhuma quase que não seja uma infecta barraca". ${ }^{4}$

Décio de Almeida Prado, ${ }^{5}$ sob a ótica do distanciamento, cita a existência de onze teatros no Rio de Janeiro, dentre os quais destaca o Teatro Lírico e o São Pedro de Alcântara como os maiores, com capacidade para 1300 espectadores.

Sobre a qualidade do teatro apresentado no Rio de Janeiro, Almeida Prado destaca a importância de Artur Azevedo. Elege sua produção a mais significativa num tempo em que prevaleciam as companhias estrangeiras ou as peças traduzidas. José Veríssimo chega a afirmar que Azevedo não foi maior porque não havia boas casas de espetáculos nem bons atores em sua época, o que dificultava o desenvolvimento do teatro.

A Capital Federal, uma das obras mais conhecidas de Artur Azevedo, é citada como exemplo do teatro brasileiro feito na época: uma comédia de costumes, com pitadas de opereta e revista. Por isso, Almeida Prado tende a chamá-la de burleta, gênero apontado pelo crítico como marcante no teatro brasileiro na passagem do século XIX para o XX.

É nesse contexto desolador, tanto na literatura em geral quanto no teatro brasileiro, que surge o nome de Júlia Lopes de Almeida, embora não seja lembrado por nenhum dos críticos até agora mencionados.

Talvez porque o teatro de autoria feminina não tivesse lugar assegurado no início do século $\mathrm{XX}$, vários são os nomes de mulheres dramaturgas que escreveram naquela época, mas foram ignoradas. Hoje, resgatadas pela ginocrítica, é possível o contato com algumas delas, dentre as quais se destacam Cecília Bandeira de Melo Rebelo de Vasconcelos (Madame Crysanthème) e Júlia Lopes de Almeida, que será objeto específico deste estudo.

\section{Uma mulher singular para época}

Júlia Valentina da Silveira Lopes de Almeida nasceu no Rio de Janeiro, em 24 de setembro de 1862. Desde cedo, mostrava sua inclinação para a escrita, embora não fosse de bom tom a mulher dedicar-se a esses afazeres. Por isso,

4 Ibid., p. 25.

5 ALMEIDA PRADO, D. de. História concisa do teatro brasileiro: 1570-1908. São Paulo: Edusp, 1999. 
MENDONÇA, C. T. Júlia Lopes de Almeida:...

fazia versos escondidos, como revelou a João do Rio, em entrevista reproduzida n’ O Momento Literário:

Pois eu em moça fazia versos. Ah! Não imagina com que encanto. Era como um prazer proibido! Sentia ao mesmo tempo a delícia de os compor e o medo de que acabassem por descobri-los. Fechava-me no quarto, bem fechada, abria a secretária, estendia pela alvura do papel uma porção de rimas...

De repente, um susto. Alguém batia à porta. E eu, com a voz embargada, dando volta à chave da secretária: já vai, já vai!

A mim sempre me parecia que se viessem a saber desses versos, viria o mundo abaixo. Um dia porém, eu estava muito entretida na composição de uma história, uma história em verso, com descrições e diálogos, quando ouvi por trás de mim uma voz alegre: - Pegueite, menina! Estremeci, pus as duas mãos em cima do papel, num arranco de defesa, mas não me foi possível. Minha irmã, adejando triunfalmente a folha e rindo a perder, bradava :- Então a menina faz versos? Vou mostrá-los ao papá!

Não mostres! - É que mostro! ${ }^{6}$

O medo de que descobrissem suas atividades literárias se justifica em função da forma como as escritoras eram vistas e tratadas na época. No século XIX, a imagem da mulher maternal e delicada foi ligada à força do bem, a partir de formulações feitas sobre a natureza feminina no século XVIII. No entanto, eralhe negada "a autonomia, a subjetividade necessária à criação". 7

Nesse contexto, é interessante que tenha estreado na imprensa por incentivo do próprio pai, que ela temera pudesse castigá-la pelo "grande crime"" de escrever versos. Foi em 1881, com um artigo sobre Gemma Cuniberti, atriz italiana que fazia teatro infantil no Brasil, publicado na Gazeta de Campinas, sua estréia nas letras. Depois, foi convidada a escrever em outros periódicos, como A Semana, quando conheceu Filinto de Almeida, com quem se casaria. 1994. p. 28 .

6 RIO, J. do. O momento literário. Rio de Janeiro: Fundação Biblioteca Nacional,

7 TELLES, N. Escritoras, escritas, escrituras. In: DEL PRIORE, M.; BASSANEZI, C. (Orgs.). História das mulheres no Brasil. São Paulo: Contexto, 2000. p. 403.

8 Expressão utilizada pela autora em entrevista concedida a João do Rio e publicada em $O$ momento literário, p. 29. 


\section{Um olhar sobre a escritora}

Reconhecida hoje, pela revisão do cânone que vem sendo feita pela crítica feminista, como um dos grandes nomes da literatura feminina do final do século XIX e início do XX, Júlia Lopes de Almeida, também em sua época, foi bastante celebrada, embora não o suficiente para que seu nome fosse destacado na história da literatura brasileira.

Na revista $A$ Mensageira, para qual contribuiu em seu número 1 e em mais alguns outros, seu nome já era citado como romancista. No número 7 dessa revista, de 15 de janeiro de 1898, Pelayo Serrano publicou um artigo intitulado Intelectualidade feminina brasileira, no qual, ao citar os nomes de brasileiras que se destacavam no cenário literário, assim se refere à escritora: "Como romancista, d. Júlia Lopes de Almeida, a mais conspícua de todas, autora da Família Medeiros, da Viúva Simões, seus romances melhores e de mais fôlego, não falando dos Traços e Iluminuras, do adorável Livro das Noivas, dos Contos Infantis..." $\mathrm{Na}$ ocasião, as obras que serão estudadas aqui ainda não haviam sido escritas, nem mesmo a peça A Herança, que foi publicada em 1909.

No entanto, o Livro das Noivas já fazia sucesso entre as jovens brasileiras que, através de sua leitura, encontravam informações que não eram fornecidas pela família.

Júlia Almeida escreveu Os Contos Infantis em parceria com sua irmã, Adelina Lopes Vieira, em 1886, e foi a primeira de suas obras destinadas às crianças; em 1907 lança as Histórias de nossa Terra e em 1917, Era uma vez. ${ }^{9}$ Note-se que sua produção infantil, numa época em que quase só se traduziam obras estrangeiras, foi significativa, embora pouco se fale sobre ela ao se estudar a história da literatura infanto-juvenil brasileira.

No início do século XX, tem-se uma citação feita por Mariana Coelho ${ }^{10}$ que, em seu livro A Evolução do feminismo, publicado em 1933, assim se refere a nossa escritora:

9 LAJOLO, M.; ZILBERMAN, R. Literatura Infantil: história e histórias. 2. ed. São Paulo: Ática, 1985. p. 29-30.

10 COElho, M. A evolução do feminismo. In: MUZART, Z. L. (Org.). 2. ed. Curitiba: Imprensa oficial, 2002. p. 331. 
MENDONÇA, C. T. Júlia Lopes de Almeida:...

Considerada a primeira escritora brasileira da atualidade, é Júlia Lopes de Almeida, que desde muito nova se dedicou com reconhecido talento às letras. As suas publicações, quase todas em prosa, são muitas e nelas se tem notabilizado principalmente como romancista. É também distinta e brilhante conferencista. A sua reputação de fina intelectual tem ecoado fora do Brasil.

Além de reforçar a importância da mulher de letras, Mariana Coelho nos mostra uma outra faceta de Júlia Lopes de Almeida, que, já naquela época, levava suas idéias para serem apresentadas em conferências, como as que fez, em 1910, sobre $A$ mulher e a arte e $A$ moda e a mulher.

Também significativa é a declaração de Filinto de Almeida que, em entrevista concedida a João do Rio, segreda:

(João do Rio) - Há muita gente que considera D. Júlia o primeiro romancista brasileiro.

Filinto tem um movimento de alegria.

Pois não é? Nunca disse isso a ninguém, mas há muito que o penso. Não era eu quem deveria estar na Academia, era ela. ${ }^{11}$

Júlia Lopes de Almeida, dentre as várias atividades que desempenhou no Rio de Janeiro, participou das reuniões para a formação da Academia Brasileira de Letras, mas ficou de fora, por ser mulher. "Seu marido, Filinto de Almeida, foi eleito membro e, até hoje, pelos cantos dos saguões comenta-se que sua eleição foi uma homenagem a ela". ${ }^{12}$ Certamente, o marido deveria ter consciência do valor de Júlia, o que fazia dela "uma mulher de sorte", que pôde contar com o apoio do pai e do marido, de dois homens, numa época em que não se abria espaço para a mulher no masculino mundo das letras.

11 RIO, op. cit., p. 33.

12 TELLES, op. cit., p. 440. 


\section{Um olhar sobre a obra}

Em seus textos, seja no formato em que for, percebe-se a luta por mudanças na situação da mulher na sociedade. Os direitos da mulher, principalmente à instrução, são tematizados, como acontece na revista $A$ mensageira, em seu primeiro número:

Não é sem algum espanto que eu escrevo este artigo, para um jornal novo, e, de mulheres! (...)

A mulher brasileira conhece que pode querer mais, do que até aqui tem querido; que pode fazer mais, do que até aqui tem feito. Precisamos compreender antes de tudo e afirmar aos outros, atados por preconceitos e que julgam toda a liberdade de ação prejudicial à mulher na família, principalmente dela, que necessitamos de desenvolvimento intelectual e do apoio seguro de uma educação bem feita.

Os povos mais fortes, mais práticos, mais ativos, e mais felizes são aqueles onde a mulher não figura como mero objeto de ornamento; em que são guiadas para as vicissitudes da vida com uma profissão que as ampare num dia de luta, e uma boa dose de noções e conhecimentos sólidos que lhe aperfeiçoem as qualidades morais.

Uma mãe instruída, disciplinada, bem conhecedora dos seus deveres, marcará, funda, indestrutivelmente, no espírito do seu filho, o sentimento da ordem, do estudo e do trabalho, de que tanto carecemos. ${ }^{13}$

Observe-se que as idéias apresentadas por Júlia Almeida, em 1897, se parecem antiquadas para os dias de hoje, para a época eram revolucionárias.

Sem negar o papel de mãe, a autora chama atenção para a mulher como indivíduo, passível de momentos difíceis, para os quais, sem instrução não estará preparada.

Além disso, é sob a perspectiva da mãe, tão valorizada pela sociedade burguesa do século XIX, que ela reivindica a instrução para a mulher: a mãe

13 ALMEIDA, J. L. de. A Mensageira. São Paulo: Imesp/Daesp, 1987. v. 1. p. 3. 
MENDONÇA, C. T. Júlia Lopes de Almeida:...

instruída pode melhor orientar os filhos e, portanto, melhor cumprir sua missão. Aproveita a existência, na época, de grupos de homens que, influenciados pelas idéias positivistas, justificavam o ensino para a mulher ligado à função materna, como uma forma de afastar as superstições e incorporar as novidades das ciências.

Júlia Lopes de Almeida não propõe à mulher que negue o papel que a sociedade espera que desempenhe, de "esposa dedicada ao marido, às crianças e desobrigada de qualquer trabalho produtivo", mas prevê a melhora do desempenho deste papel.

Talvez esteja aí o segredo de sua aceitação: sem ir contra as regras estabelecidas pela sociedade para a mulher, usa essas mesmas regras como argumento para reivindicar condições que, sabidamente, dariam à mulher a independência em relação ao homem.

Essas idéias aparecem em suas obras ficcionais, como é possível constatar a seguir.

\section{As narrativas}

Autora de vários romances, como A Intrusa, Correio da Roça, Memórias de Marta, Cruel Amor, A Viúva Simões e A Falência, Júlia Almeida é mais conhecida como romancista que dramaturga, embora seus textos dramáticos, como se verá, sejam considerados, também pelos homens da época, como bons.

Também escreveu contos, reunidos em Traços e Iluminuras e em Ânsia Eterna, este considerado por alguns críticos como um de seus melhores trabalhos.

Das obras citadas, duas foram escolhidas para análise, em função de serem apontadas pela crítica contemporânea como bons "exemplos de plena realização literária": ${ }^{14}$ A Intrusa e A Falência.

Embora na entrevista concedida a João do Rio, anteriormente citada, Júlia Lopes de Almeida tenha respondido de forma evasiva a propósito do feminismo ("Acabo de receber um convite de Júlia Cortines para colaborar numa revista dedicada às mulheres. Descanse! Há uma seção de modas, é uma revista

14 Elódia Xavier, em prefácio à edição de $A$ Intrusa, realizada pela Biblioteca Nacional, apresenta um estudo sobre a obra, que embora seja bastante citada por várias estudiosas, não parece ter recebido, ainda, atenção merecida. 
no gênero Femina..."), ${ }^{15}$ essas narrativas são marcadas por questões amplamente discutidas pelo feminismo da época.

Neste estudo, serão focalizados dois temas principais: a instrução feminina e o casamento na vida da mulher, temas recorrentes em sua obra, inclusive na dramática.

A princípio, será feita apenas uma breve leitura das narrativas, a fim de alinhá-las com a dramaturgia, que é o principal objeto desta pesquisa.

\section{A instrução}

Já em A Falência, publicada em 1901, a idéia da necessidade de estudo para mulher estava presente, embora de forma pouco explícita.

Francisco Teodoro, um grande negociante de café, por imprudência nos negócios, vai à falência e perde a capacidade de sustentar a família. Ao ver-se diante da miséria, mata-se, deixando todos desamparados. Camila, a esposa, não possuía instrução. Com a morte do marido, teria que contar com o apoio de uma agregada e da empregada Noca, que passaria a engomar roupa para fora. $\mathrm{Ou}$ seja, por não ter como sustentar-se, ela e suas filha teriam que, dali para frente, contar com a caridade de pessoas amigas.

Camila era infiel ao marido. Há muito mantinha um relacionamento amoroso com o médico da família e, ao ver-se sozinha, enche-se de coragem e propõe casamento ao amante. Este, no entanto, diz-lhe que já era casado e que, portanto, não poderia se casar de novo.

Ao perceber que não pode contar com os homens para ser feliz, Camila, que não estudara além do necessário para ser uma boa dona de casa, agora terá que contar apenas com o seu trabalho e o das outras mulheres que com ela vivem. Não estava preparada para isso. Tivera uma vida de futilidades, festas e aparência. Ainda assim, diante da possibilidade de perder as filhas, decide prosseguir sozinha: encontra forças para trabalhar e dispõe-se a viver sem um homem, apenas da colaboração daquela sociedade feminina.

No entanto, isso não acontecerá com suas filhas: Ruth já toca violino e ganha algum dinheiro dando aulas particulares e as gêmeas serão educadas, para que não passem pela mesma situação da mãe.

15 Esta entrevista está reproduzida em $O$ Momento Literário, obra organizada por João do Rio a partir de entrevistas concedidas por autores representantes da época. 
Júlia Lopes de Almeida parece, com este romance, querer alertar as mulheres para a situação em que a maioria delas se encontraria, caso ficasse viúva, para mais tarde, em $A$ Intrusa, apresentar-lhes uma alternativa para a situação.

É interessante notar que embora o discurso da mulher Júlia, quando entrevistada, deixe nas entrelinhas que não é feminista, suas personagens são questionadoras, colocam em xeque o destino reservado à mulher - o domínio da casa - e reproduzem o discurso de jornais libertários que apontavam a instrução como uma "arma privilegiada de libertação" para a mulher, ${ }^{16}$ assim como também existiam escolas libertárias que se preocupavam com a instrução das meninas.

Destaca-se, também, a idéia inovadora para a época: um lar só de mulheres, que não precisam da tutela masculina para sobreviver, que são capazes de gerar seu sustento.

Se observarmos que naquele tempo as mulheres "de família" sequer andavam sozinhas pela rua, será fácil dimensionar a ousadia desta idéia. A própria Júlia Lopes de Almeida, quando desejava pesquisar junto aos pescadores as idéias para um de seus livros, saía acompanhada do filho, pois não era de bom tom andar sozinha.

A Intrusa (1905), um de seus romances mais conhecidos, traz a governanta Alice como representante das idéias da autora sobre a necessidade de a mulher estudar.

Ao ler um anúncio no jornal, Alice se apresenta para a colocação de governanta e é considerada uma oportunista, que tem como intenção infiltrar-se na casa de um homem viúvo bem sucedido para casar-se. No decorrer da narrativa, a leitora (afinal, os romances de Júlia parecem ter como leitores-modelo as mulheres) toma conhecimento de certos refinamentos de educação que só seriam possíveis em uma mulher instruída e que colaboram para que se construa uma imagem de respeito em torno da personagem.

Ao final, revela-se que é moça de boa família, educada num dos melhores colégios da França, e que, com a morte do pai, ao ver-se na miséria, tem em sua instrução uma forma de recomeçar a vida. A instrução esmerada vale à moça a admiração de Argemiro, que encontra seus livros em inglês e percebe a capacidade que ela tem para instruir a filha, Maria da Glória, considerada mal-educada.

Com o convívio entre Alice e a menina, Argemiro percebe as mudanças pelas quais a filha passa e, por isso, tende a admirar mais a governanta, que só

16 LOURO, G. L. Mulheres na sala de aula. In: DEL PRIORE; BASSANEZI, op. cit., p. 446 . 
vira uma única vez: "A minha governanta lia inglês! Foi a sua primeira revelação. Depus o livro fechado sobre a mesa e vi o nome dela escrito na capa. Para simpatizar com ela bastaria, talvez, isso; - para respeitá-la, o modo por que tem sabido corrigir Glória das suas brutalidades de menina malcriada". ${ }^{17}$

Novamente temos a idéia de que a mulher instruída é a ideal para gerenciar uma casa e cuidar das crianças. Note-se que a instrução ainda não é específica para uma formação profissional, mas voltada para o desempenho dos papéis de mãe e esposa.

No entanto, o fato é que a instrução surge como fator positivo para a mulher. Ter estudado garante à mulher o direito de gerenciar sua vida, sem estar tutelada pelo marido, pelo irmão ou pelo pai.

Por outro lado, ao contrário de Arnolfo, personagem de Molière, que deseja sua Inês ignorante de todo, Argemiro aspira por uma mulher educada, que possa desempenhar o papel de esposa e mãe, segundo visão influenciada pelo Positivismo e que era comum na época. Nesse sentido, a autora chega a destacar os ensinamentos de Alice a Glória sobre as plantas, os animais, sempre sob o enfoque científico, aliás questionados pela sogra de Argemiro, que os vê como "coisas de homem". No entanto, é por Alice cumprir as expectativas que ele se descobre apaixonado pela alma de uma mulher, sem mesmo saber de seu corpo.

Utilizando personagens femininas em posições ideológicas diferentes, a autora obriga a leitora a refletir e se posicionar frente à situação da mulher na sociedade.

\section{O casamento}

Em A falência, o casamento surge para Camila como uma forma de assegurar o futuro. Era de família pobre, mas de educação (o que não significava instrução, mas conhecimentos de prendas domésticas), era bonita e grave e, por tudo isso, a esposa ideal para Teodoro, que começava a solidificar sua fortuna. Casaram em pouco tempo, depois de acertos entre a família dela - que foi fartamente presenteada por ele - e Teodoro. Nunca se falou em amor. Na verdade, o narrador explica que "Tinham-se acostumado um ao outro, viviam em paz". ${ }^{18}$ Teodoro conhece outra mulher, com quem tem um caso, mas não deixa que nada

17 ALMEIDA, op. cit., p. 109.

18 Ibid., p. 18. 
falte à esposa. Esta, mais tarde a leitora descobre, embora soubesse da infidelidade do marido, não diz nada, para não colocar em perigo sua tranqüilidade.

Assim é que, quando conhece o dr. Gervásio, Camila passa a viver uma relação paralela com ele que, por ser médico da família, tinha livre trânsito na casa, sem despertar as desconfianças do marido. O casamento a três se arrasta por longos anos, salvaguardado pelas aparências: Camila tinha a segurança dada pela situação financeira de Teodoro e vivia com Gervásio o amor que nunca tivera com o marido.

Há que se notar a ousadia da situação apresentada por Júlia Lopes da Almeida. Se, a princípio, a mulher casa-se apenas por interesse, durante o casamento ela deixa de ser primeiro esposa e mãe para ser mulher. Quando o filho, Mário, revela que sabe sobre o caso da mãe, esta não hesita em casá-lo com uma moça rica, que mal conhecia, para ficar mais livre e viver a sua paixão.

O leitor de hoje, acostumado aos valores do século XIX, espera que essa ousadia seja punida, como sempre acontecia, como ocorreu com Ema Bovary ou com Capitu. No entanto, Camila, ao perceber que Gervásio não a vai assumir, que sua atitude poderá comprometer para sempre seu papel de mãe e sua dignidade, afasta-se dele e resolve viver sozinha, apenas com as filhas e agregadas. O que deveria ser um castigo revela-se prêmio: a liberdade em relação ao homem. $\mathrm{O}$ casamento já não é a única razão de viver para a mulher.

Ao discutir essas idéias a partir de suas personagens, Júlia Lopes de Almeida faz com que não se crie entre ela, sua obra e a crítica - marcada pelo falocentrismo - um clima ruim, como aconteceu com Mme. Chrysanthème que, ao pronunciar-se abertamente a favor da causa feminina no prefácio de um de seus romances, despertou a fúria da crítica machista.

Outro aspecto para o qual se deve chamar atenção é para a personagem Ruth, a filha de Camila, na qual Júlia coloca a possibilidade da mulher afastada do estereótipo feminino: a menina não gosta de brincar de bonecas, prefere as árvores, gosta de tocar violino, é questionadora, tem uma visão "masculina" do mundo e, por isso, quando a família se encontra na miséria, é ela que tem a possibilidade de renda através de seu trabalho: dá aulas de violino, apesar de sua pouca idade.

Em $A$ Intrusa, a questão do casamento não é apresentada por Alice. $\mathrm{Na}$ verdade, é uma personagem que pouco se revela. O que sabemos sobre ela é mais o que os outros personagens falam do que percebemos pelo contato.

Alice mostra-se preocupada apenas em trabalhar para sobreviver e não em casar. É Argemiro que vê nela a esposa ideal. Desde o início da narrativa ele 
declara: "uma casa sem mulher é um túmulo com janelas: toda vida está lá fora!" 19

O casamento acontece na última página do livro e é secamente contado. Não há referências à Alice, nem antes nem depois. Acredita-se que ame Argemiro porque a baronesa declara ao genro que tem certeza do sentimento que a governanta nutre por ele. No entanto, ele nega essa possibilidade, uma vez que não havia contato entre eles, não se viam nunca, não se falavam, não se tocavam. A resolução do casamento se dá pela remoção do problema: Alice é de boa família, não é uma interesseira e, ainda melhor, segundo a sogra, está apaixonada por Argemiro.

A questão do casamento, no entanto, é preocupação de outra personagem, que não é a protagonista, mas aspira ao casamento com Argemiro.

Segundo Maria Ângela D'Incao, a mulher, na casa burguesa, era figura indispensável. "Cada vez mais é reforçada a idéia de que ser mulher é quase ser totalmente mãe dedicada e atenciosa(...) Os cuidados e a supervisão da mãe passam a ser muito valorizados (...) das mulheres passa a depender também o sucesso da família, quer em manter seu elevado nível e prestígio social já existentes, quer em empurrar o status do grupo familiar mais e mais para cima". ${ }^{20}$

É a partir dessa idéia que se constrói a personagem Pedrosa. Mulher decidida, apontada por Elódia Xavier como "uma espécie de homem de saias"21 é ela a responsável pelo crescimento do marido na política. Casou-se por amor, "mas também por ver em teu pai um homem de altas tendências.(...) Homem que casar com mulher acomodada, está perdido"22 e não esconde da filha, a quem dá o exemplo:

Quando me casei, teu pai não passava de um advogado pobre... Quem o lançou na política? Fui eu. Quem trabalhou para sua eleição de deputado e que maior número de votos alcançou? Fui eu. Quem o levou pela primeira vez ao paço de suas Majestades? Fui eu, e tinha apenas vinte e dois anos! (...) Quem o fez ministro agora? Eu. Eu sempre, servindo-me destas estratégias, aproveitando todas as ocasiões e todas as simpatias, (...) seguindo-

19 ALMEIDA, op. cit., p. 3.

20 D'INCAO, M. Â. Mulher e família burguesa. In: DEL PRIORE; BASSANEZI, op. cit., p. 229.

21 XAVIER, E. Prefácio. In: ALMEIDA, J. L. de. A intrusa. Rio de Janeiro: Fundação Biblioteca Nacional, 1994. p. 4. 
o como um cão de caça segue o caçador, através de todos os perigos, corajosamente.

Dona Pedrosa havia desempenhado o papel que a sociedade esperava da mulher: havia se dedicado à carreira do marido, à sua ascensão e conseguido sucesso. Agora, restava-lhe ensinar à filha o exemplo a seguir.

No entanto, Sinhá mostra-se assustada com tudo isso e não quer seguir as indicações da mãe. Faz um trato de amizade com Argemiro e sai em busca do amor, que acaba encontrando.

É também pelas conversas entre Sinhá e sua mãe que o divórcio surge como tema. Nessa discussão fica clara a visão que a moça tem do matrimônio: "A grande poesia do casamento parecia-lhe estar na perpetuidade do amor e do voto. Que era o casamento, então? Um contrato quebradiço, sujeito a ser violado ao primeiro amuo?"23 O romantismo da moça contrasta com a praticidade da mãe, gerando um conflito que aumentará na medida em que a moça se nega a cumprir o que a mãe espera dela e a fazer um casamento por interesse, com um homem mais velho, que lhe desse conforto e segurança.

Como se vê, Júlia Lopes de Almeida cria personagens de posições diferentes em relação ao casamento para que se possa discuti-lo, rever a situação da mulher no consórcio matrimonial, que, de modo geral, deixava de lado a felicidade feminina para concentrar-se no homem e na prole.

\section{A obra dramática}

O feminino tem sido tematizado pela dramaturgia ao longo dos tempos. No teatro brasileiro do século XIX, França Júnior, na peça As Doutoras (1890), aborda essa questão sob um prisma que é caro à nossa autora: a importância da instrução na vida da mulher.

Décio de Almeida Prado,${ }^{24}$ comentando a peça de França Júnior, chama atenção para o fato de ser uma peça de tese, que já envelheceu, em função das idéias que defende. Nela, o autor discute o tipo de instrução que a mulher

22 ALMEIDA, op. cit., p. 79.

23 Ibid., p. 65.

24 ALMEIDA PRADO, op. cit., p. 137. 
deveria receber, limitando-a ao ensino do piano e dos idiomas, ou seja, aos elementos necessários para o bom desempenho nos salões, onde sua presença contribuiria para o desenvolvimento da carreira do marido. Diplomas deveriam ser reservados apenas para homens. É uma visão preconceituosa, mas que encontrava respaldo nas idéias da época.

A própria Júlia Lopes de Almeida, ao falar de sua paixão pela leitura, na entrevista concedida a João do Rio, confessa que faz seus romances aos poucos, depois do almoço, quando as coisas ficam mais tranqüilas, pois uma dona de casa não pode perder tempo lendo, embora ela pudesse passar o resto de sua vida a ler. Como se vê, a idéia da leitura é a de ociosidade, mas "Quem cuidaria dos filhos, dos arranjos da casa?" 25 Hoje, ao lermos essa declaração aparentemente tão conservadora, custa-se a crer que tenha sido feita pela autora de $A$ Herança. É difícil que não se procure nessas palavras a estratégia que percebemos em sua ficção, embora não se possa ignorar que a escritora nunca rompeu com a situação de mãe e esposa.

A obra dramática de Júlia Lopes de Almeida não é de fácil acesso, pois parte dela foi publicada em um único volume, editado em Portugal, no Porto, em 1917, pela editora Renascença Portuguesa, que reúne Quem não perdoa, Doidos de Amor e Nos Jardins de Saul. No Brasil, publicou-se, em 1909, no Jornal do Comércio, a peça $A$ Herança, que servirá como referência para o estudo desta sua faceta.

Quem não perdoa é um drama em três atos encenado no Teatro Municipal do Rio de Janeiro, em 1909. Trata de um casamento em que o marido Gustavo trai a mulher, Ilda, que lhe é fiel. No entanto, Ilda se apaixona por um amigo e, embora vivesse um amor platônico, passa a sentir-se imensamente feliz. Manoel, o amado, deve partir para a Europa e os dois se despedem quando são surpreendidos pelo marido, que a mata, alegando defesa da honra. É preso, mas ao fim de catorze anos, quando de novo está em liberdade, é aclamado pelos amigos como herói. No entanto, a sogra, dona Elvira, que não lhe perdoa a infelicidade da filha, assassina-o.

Outro aspecto do casamento é discutido: o homem tem licença para ser infiel, é natural que assim o seja, e à mulher cabe não só aceitar como sublimar essa traição. Não há espaço para que busque a felicidade com outro. A mulher é traída, infeliz, não tem direito a refazer sua vida, é morta por algo que não fez e o homem é exaltado por sua morte. Ao colocar esse tema numa peça, a autora não só chama atenção para a situação da mulher no casamento como a faz pensar sobre uma outra possibilidade, sobre as injustiças da sociedade em relação à

25 ALMEIDA, op.cit., p. 35. 
mulher. A mãe de Ilda não vê tudo que aconteceu como algo normal. Há uma divergência entre a visão masculina e a feminina, que não mais aceita como natural a morte da mulher pelas mãos do marido.

Outro aspecto interessante é que o matrimônio não é mais colocado como um mar de rosas para a mulher. Dona Elvira, a "raisonnneuse", discute em suas falas as idéias sobre o casamento, que a dramaturga quer pôr em questão: "Na vida de uma mulher solteira, por maior que seja o sofrimento, há sempre a esperança. $\mathrm{Na}$ da casada, quando não haja felicidade há apenas resignação". ${ }^{26}$

Observe-se que, nessa fala, o casamento traz à mulher a falta de perspectiva e a condição de solteira pode ser mais promissora que a de casada, ao contrário do que a sociedade, que via no matrimônio a razão da existência feminina, pregava. Mais uma vez, Júlia Lopes de Almeida traz, em seus textos, uma perspectiva diferente para a mulher.

A questão do casamento é discutida também na comédia Doidos de amor, na qual Joana Telles deseja fugir para não se casar com o rapaz a quem seu pai a havia destinado. Conhece Antero, os dois se apaixonam e, afinal, descobrem que eram os prometidos pelos respectivos pais para o casamento. Se a solução encontrada para o impasse não é inovadora - até bastante comum no teatro - o tema traz, mais uma vez, a possibilidade de reflexão sobre a situação da mulher no casamento, sobre a possibilidade de haver uma escolha do cônjuge, sobre o amor entre eles, que então não era vista como questão fundamental para o casamento.

Em $A$ Herança, essas questões também são desenvolvidas.

Convidada por Artur Azevedo para apresentar sua obra na estréia do Teatro da Exposição Nacional, na Praia Vermelha, em 12 de agosto de 1908, Júlia cria $A$ Herança, drama em 1 ato. A peça conta a história de Elisa, que se casara com separação de bens, por sugestão da sogra, que a julga ambiciosa. Pouco tempo depois, o marido fica tuberculoso. Sem fugir a seu papel de esposa, Elisa dedica-se totalmente a ele, sem ao menos resguardar-se, e acaba também ficando doente. Quando o marido morre, sem ter para onde ir nem como sustentar-se, continua na casa da sogra, onde é tratada como empregada por esta e pelas cunhadas, sem revelar seu estado de saúde.

Quando o médico é chamado e sua doença diagnosticada, a sogra mostrase desejosa de afastá-la de sua casa, numa total falta de gratidão pelos cuidados que um dia Elisa dedicara ao filho. Humilhada, Elisa revolta-se, enfrenta a sogra

26 SOUZA, M. C. A tradição obscura: o teatro feminino no Brasil. Rio de Janeiro: Bacantes, 2001. p. 50. 
e depois deixa a casa, em meio a um temporal, o que nos faz pensar em suicídio, pois estava gravemente doente e febril.

Enquanto conversava com o dr. Seabra, Elisa revela a ele o fato de ter interrompido os estudos para casar, o sonho de ser professora. Era normalista, faltava pouco para formatura, mas o marido exigira que abandonasse os estudos.

Como já se viu, a educação para a mulher, nas obras analisadas até agora, surge em função principalmente dos papéis de mãe e esposa. Nesta peça, a instrução é para a mulher, que busca sua realização profissional, não em função do marido, por isso é negada.

No século XIX e no início do XX, a atividade docente, que a princípio era ocupação dos homens, passa a ser desempenhada pelas mulheres, como uma continuação do papel materno, que lhe garantia o dom natural para o trato com crianças. É nessa época em que o magistério é associado com características tidas como essencialmente femininas, como paciência, afetividade, doação...

Apesar disso, as normalistas eram cercadas de "restrições e cuidados para que sua profissionalização não se chocasse com sua feminilidade". A docência não deveria atrapalhar a verdadeira carreira feminina: o casamento. Por isso, o magistério era visto como uma atividade transitória, um "espera marido", que por ocasião do matrimônio seria abandonado, pois a sua manutenção seria vista como sinal de masculinização.

Tal procedimento é reproduzido pela personagem de Júlia Lopes de Almeida, mas é necessário examinar a forma como esses fatos são apresentados: Primeiro, Elisa adora estudar, não faz a escola normal apenas enquanto não se casa. Tem sonhos de realização profissional, de crescimento em termos de conhecimento: almeja ir além da cozinha. Acreditava que pelo estudo um dia chegaria a "ser alguém". Segundo, ao ser obrigada a abandonar a escola, lamenta, não encara o fato naturalmente, como deveriam encarar todas as moças, já que o trabalho fora de casa era vetado à mulher. Terceiro, somente ao lembrar de sua época de estudante se diz feliz. - O casamento, que deveria ser o mais importante, não é apontado como a época mais feliz de sua vida. Quarto,vê a saída da escola normal como um desastre. São palavras de Elisa: "no fim [do curso] estava a minha independência, o meu futuro assegurado" (p. 34). Ela vê sua carreira como forma de realização profissional, era sua vocação.

É possível notar que, apesar de aparentemente reproduzir o discurso da época, são colocadas na personagem algumas particularidades que a diferenciam da maioria das mulheres.

Se ao final Elisa busca a morte, é porque não tem perspectiva de vida melhor: está condenada, tanto pela saúde como pela dependência. Mesmo que voltasse a estudar, sua doença não lhe permitiria ter contato com as crianças. 
MENDONÇA, C. T. Júlia Lopes de Almeida:...

Jamais poderia exercer sua profissão. O estudo, para ela, não era questão de distração, como sugere o doutor, mas uma perspectiva de vida, por isso não pode voltar a ele. Nada mais lhe resta, não há por que não apressar a morte.

Como se pode perceber, o efeito de tal personagem, certamente, não deixará de se fazer dentre os(as) espectadores(as). No entanto, nada há que, aparentemente, subverta a ordem.

A peça é curta - apenas um ato, com 25 minutos de duração, como apontam as notas que acompanham sua publicação, com os diálogos curtos -, não foge ao padrão do teatro doméstico, tão em voga na época.

As cenas são passadas no interior da casa, em um cômodo. Na rubrica inicial que caracteriza o cenário é possível perceber como os objetos são meramente decorativos, e que não faltam dois elementos constantes da obra desta autora: os livros e as flores.

Outro aspecto interessante é que o conflito maior se dá entre mulheres, não entre um homem e uma mulher. É a sogra a responsável por representar a sociedade da época. Não é feliz desempenhando seu papel de dona de casa, mas é incapaz de ver de forma solidária a situação de Elisa. Há uma disputa entre dona Clementina e Elisa: se esta carrega as chaves da despensa na cintura, aquela é quem controla tudo, inclusive os mantimentos usados durante o mês ou a semana. Percebe-se que o papel da mulher, como reprodutora de uma ideologia machista, também é colocado em pauta, uma vez que dona Clementina age como homem, controlando tudo. Também, deve se notar a presença maciça de personagens femininas (dona Clementina, Elisa, Rita e Benvinda), o que facilita que se discutam as questões femininas.

Apesar da temática interessante, percebe-se que o texto não inova na concepção de teatro da época: o cenário é convencional, o palco nunca está vazio, os diálogos são rápidos e a estrutura da peça obedece à fórmula francesa da "pièce bien faite". Embora tenha um único ato, há uma nítida divisão ternária que nos indica a apresentação do conflito (a situação de Elisa na casa da sogra), a complicação (a constatação de sua doença) e o desfecho (o atrito com a sogra e a saída de Elisa). Note-se que, com a preocupação maior em discutir a questão feminina, o aspecto dramatúrgico fica em segundo plano. Não se pode negar que o desenvolvimento do conflito é fraco, que a conclusão é um tanto precipitada e que, em certos momentos, a leitura da peça muito se assemelha à de um conto.

Olavo Bilac chama atenção para a extensão da peça e afirma que se teria como desenvolver três atos a partir do conflito apresentado. Em função do pouco tempo reservado às apresentações ou por estrategicamente não querer se alongar nas discussões sobre a mulher, a peça deixa a sensação de que havia 
muito a ser dito e vivido. Faltou força ao conflito, que poderia não enfatizar tanto o sentimentalismo, para discutir melhor as questões sociais.

Apesar disso, cumpre a missão de alertar o público feminino. O próprio Olavo Bilac atesta seu efeito ao declarar: "Uma tragédia, sim, por mais estranho que isso pareça, - uma tragédia que deixa na alma de quem a ouve a impressão duradoura e forte, que só pode ser provocada pelas obras de grande arte". ${ }^{27}$

Também Artur Azevedo fala sobre o efeito da peça: "Não sei que efeito A Herança produzirá no público (...) é, talvez, a mais sincera de todas as peças, novas e velhas, exibidas e ainda por exibir no teatro da Exposição". ${ }^{28}$

As outras críticas, tanto a de O Paiz como a do Jornal do Commercio, referem-se a ela como "um drama real", da "psicologia social", o que mais enfatiza o poder de reflexão que a peça possa alcançar: se retrata a realidade, deve ser vista como um alerta para as mulheres. No entanto, não há notícia de que esta peça tenha sido remontada.

Hans Robert Jauss ${ }^{29}$ nos fala que "a tarefa da história da literatura somente se cumpre quando a produção literária é não apenas apresentada sincrônica e diacronicamente na sucessão de seus sistemas, mas vista também como história particular, em sua relação própria com a história geral”. Neste sentido, as críticas acima nos dão a idéia da recepção da obra na época de sua representação e também nos permitem inseri-la num contexto dramatúrgico, no qual parece se destacar por sua temática e verossimilhança.

Para que se perceba hoje o valor de tal obra é fundamental que se leve em conta, além da recepção, também os modelos que existiam, em relação aos quais a obra de Júlia Lopes de Almeida se destaca.

Ao final da leitura de parte da obra desta autora, algumas considerações devem ser feitas.

A preocupação com a situação da mulher na sociedade parece incontestável, uma vez que está presente tanto em sua obra dramática quanto romanesca. Nota-se mesmo um aprofundamento crescente, quando a autora deixa de tematizar apenas essas questões sob o ponto de vista positivista, higienizador, como era comum na época, para passar a discutir a situação da mulher não só na família, mas sua cidadania, sua possibilidade de ter voz e vez, como faz tanto em A Falência quanto em A Herança.

As posições que parecem ser conservadoras e reprodutoras de uma visão sectária em relação à mulher podem e devem ser vistas como estratégias

27 Fortuna crítica anexada à publicação feita em 1909, à guisa de prefácio.

28 Id.

29 JAUSS, H. R. A história da literatura como provocação à teoria literária. São Paulo: Ática, 1994. p. 51. 
MENDONÇA, C. T. Júlia Lopes de Almeida:...

para que sua obra não crie conflitos frontais com a crítica falocêncrita, que a condenaria ao anonimato. Suas personagens, mesmo de forma disfarçada, estão sempre a questionar seus papéis na sociedade.

A temática da instrução, por exemplo, que parece ser tratada de acordo com a visão positivista, quando olhada pelo prisma de um direito adquirido que pode levar à independência da mulher, torna-se um instrumento de mudança. Além disso, esse tema não é discutido apenas sob esse aspecto. A peça $A$ Herança apresenta não só a instrução para melhor desempenho do papel de mãe e esposa, mas uma finalidade para a vida da mulher, uma alternativa de ganhar uma identidade própria, ser alguém através da realização profissional.

Também o casamento é discutido de forma especial. Suas personagens não o vêem como finalidade de sua existência - pensamento corrente na época -, mas como parte sua vida, que nem sempre é feliz. Observe-se que há um distanciamento da visão romântica, em que o final feliz incluía o matrimônio. Das narrativas lidas, a única que termina em casamento - A Intrusa - não o apresenta como algo esperado e festejado. Se, por um lado, o casamento de Alice ainda é visto como premiação para a mulher, é também verdade que há outra personagem que o questiona, como é o caso de Sinhá, quando não aceita a imposição da mãe. Desta forma, não há apenas um modelo a ser seguido por todas; a autora apresenta uma possibilidade de escolha.

Nas outras obras, o casamento aparece mais como motivo de sofrimento que de felicidade. Se Camila se casou por interesse, não foi feliz com o marido e teve que suportar a dor de ser traída, até que encontrasse um amor que a realizasse. Por outro lado, enquanto via o casamento como uma solução financeira, não pôde ser feliz, já que o amante não deseja assumi-la para casar-se. Camila então percebe que pode viver sem se casar, que pode ser feliz em sua casa, com suas filhas, sem a proteção masculina. Este é um grande avanço para a época, quando a mulher não possuía autonomia alguma.

Também em A Herança o valor do casamento é questionado, uma vez que ao abrir mão de sua identidade para casar-se, Elisa não encontra a felicidade. Para ela, o casamento foi por amor, mas gostaria de ter continuado seus estudos, ter seguido uma carreira, ter desenvolvido seu potencial intelectual. Desta forma, o casamento seria parte de sua vida, não a finalidade dela.

Por tudo isso, pode-se chegar à conclusão de que se Júlia Lopes de Almeida não inova na proposta estética de suas obras, por seu papel questionador, pela ousadia na criação de personagens femininas merece destaque em sua época. Além disso, a peça $A$ Herança, dentro do conjunto de sua obra, é aquela em que se percebe maior questionamento sobre a situação de desamparo 
em que a mulher se encontra quando abre mão de todos os outros interesses para dedicar-se somente ao papel de esposa.

Finalmente, conclui-se que o nome desta autora pode e deve ser incluído no rol das autoras inovadoras, pois bem ao jeito feminino, conseguiu levantar e discutir questões de suma importância para a mulher de sua época, sem que com isso tivesse sua obra condenada pela crítica que, se não a incluiu no rol dos grandes nomes da literatura brasileira, elogiou-a e permitiu que continuasse a questionar o modo como as mulheres viviam. Júlia Lopes de Almeida conseguiu ser mais que criatura, tornou-se criadora, numa época em que a pena era instrumento essencialmente masculino.

\title{
RESUMO
}

Este ensaio pretende apresentar uma leitura da obra de Júlia Lopes de Almeida, tomando por base as narrativas $A$ Intrusa e $A$ Falência, além de enfocar de modo especial a peça $A$ Herança. Pretende-se apontar a existência de um fio condutor na obra desta autora, que é a questão feminina, discutida principalmente sobre o aspecto do casamento e da instrução na vida da mulher do entresséculos.

Palavras-chave: Júlia Lopes de Almeida, feminino, entresséculos.

\begin{abstract}
The present article analyses the narratives $A$ Intrusa e $A$ Falência, writen by Júlia Lopes de Almeida, and the role $A$ Herança. It intends to show un lead through the works, the femine question, saw by the point of the wedding and the instruction in the woman's life of the end of the century XIX and the beginning of the century XX.

Key-words: Júlia Lopes de Almeida, feminism, turn of century.
\end{abstract}


MENDONÇA, C. T. Júlia Lopes de Almeida:...

\section{REFERÊNCIAS}

ALMEIDA, J. L. de. A Falência. São Paulo: Hucitec, 1978.

. A Intrusa. Rio de Janeiro: Fundação Biblioteca Nacional, 1994.

. A Herança. Rio de Janeiro: Tipografia do Jornal do Commercio, 1909.

A Mensageira. São Paulo: Imesp/Daesp, 1987. v. 1. p. 3.

BRITO, M. da S. História do modernismo brasileiro. 6. ed. Rio de Janeiro: Civilização Brasileira, 1997.

COELHO, M. A evolução do feminismo. In: MUZART, Z. L. (Org.). [c/ autor: obra?] 2. ed. Curitiba: Imprensa Oficial, 2002.

COELHO, N. N. Literatura: arte, conhecimento e vida. São Paulo: Petrópolis, 2000.

DEL PRIORE, M. A mulher na história do Brasil. 3. ed. São Paulo: Contexto, 1992.

; BASSANEZI, C. (Orgs.). História das mulheres no Brasil. São Paulo: Contexto, 2000.

DUBY, G.; PERROT, M. (Dir.). História das mulheres no ocidente. Porto: Afrontamento, 1991. v. 4 - O século XIX.

JAUSS, H. R. A História da Literatura como provocação à Teoria Literária. São Paulo, Ática, 1994.

LAJOLO, M.; ZILBERMAN, R. Literatura Infantil Brasileira: História \& Histórias. 2. ed. São Paulo: Ática, 1985.

ALMEIDA PRADO, D. de. História concisa do teatro brasileiro: 1570-1908. São Paulo: Edusp, 1999.

RAMALHO, C. (Org.). Literatura e Feminismo: propostas teóricas e reflexões críticas. Rio de Janeiro: Elo, 1999.

RIO, J. do. O Momento Literário. Rio de Janeiro: Fundação Biblioteca Nacional, 1994.

SOUTO-MAIOR, V. A. Índice das dramaturgias brasileiras do século XIX. Florianópolis: Ed. Mulheres, 1996.

SOUZA, M. C. de. A tradição obscura: teatro feminino no Brasil. Rio de Janeiro: Bacantes, 2001.

VERÍSSIMO, J. O que é Literatura? e outros escritos. São Paulo: Landy, 2001. 